\title{
Incidental Appendiceal Mucinous Neoplasms in Patients Who Underwent Right Hemicolectomy
}

\author{
Sağ Hemikolektomi Hastalarında insidental Olarak Saptanan \\ Apendiksin Müsinöz Neoplazmları
}

\author{
Salih $\operatorname{Tosun}^{1 \oplus}$, Oktay Yener ${ }^{1 \oplus}$, Ozgur Ekinci $^{1 \oplus}$, Ihsan Metin Leblebici ${ }^{1 \oplus}$, Ahmet Yusuf Serdaroglu $^{1} \mathbb{C}^{\oplus}$ \\ ${\text { Mehmet } \text { Acar }^{1} \oplus, \text { Tuce Soylemez }^{2} \oplus \text {, Orhan Alimoglu }}^{1}$ (๑)
}

${ }^{1}$ Istanbul Medeniyet University, School of Medicine, Department of General Surgery, Istanbul, Turkey

${ }^{2}$ Istanbul Medeniyet University, School of Medicine, Department of Pathology, Istanbul, Turkey

Received: 24 March 2020 / Accepted: 16 April 2020 / Publication date: 26 June 2020

Cite as: Tosun S, Yener O, Ekinci O, Leblebici iM, Serdaroğlu AY, Acar M, Soylemez T, Alimoglu O. Incidental appendiceal mucinous neoplasms in patients who underwent right hemicolectomy. Med J Bakirkoy 2020;16(2):160-4.

\section{ABSTRACT}

Objective: Subclinical appendiceal mucinous neoplasms (AMNs) may accompany abdominal malignancies which must be considered during colectomies. We aimed to evaluate the treatment and follow-up approach to the patients in whom incidentally appendiceal mucinous neoplasm detected following right hemicolectomy performed for abdominal malignancies.

Method: The records of the patients who underwent right hemicolectomy due to benign or malign conditions in our general surgery clinic between January 2016 and December 2019 were analyzed. After the exclusion of the patients who had undergone hemicolectomies due to benign causes and appendiceal pathologies detected before the operation, the records of remaining patients' were evaluated. The patient records who underwent right hemicolectomy for gastrointestinal or gynecologic malignanacies were analyzed. The patients whose pathology results were reported as AMNs were included in the study. The incidence of $A M N$ was analyzed and compared with the literature.

Results: Hundred and sixty-seven of the 214 patients with gastrointestinal or gynecologic malignanacies were included in this study. Eighty patients were female and 87 were male. The mean age was 63 (23-95) years. The incidence of AMN was $2.9 \%$ in patients who underwent right hemicolectomy for malignity in three years period. According to the pathology reports; 3 patients (60\%) had appendiceal mucinous neoplasia, one patient (20\%) appendiceal mucinous cystadenocarcinoma and one (20\%) appendiceal carcinoid tumor.

Conclusions: Ilncidentally detected AMN is a rare entity and should be considered during the right hemicolectomy operations of different malignancies. Resections must follow principles for malignancy surgery. The preoperative evaluation of the patients needs attention, their postoperative treatment must be planned according to the pathology reports and the patients must be followed for any potential accompanying colorectal tumors.

Keywords: appendectomy, incidental, tumor, appendiceal neoplasm

öz

Amaç: Subklinik apendiks müsinöz neoplazmları (AMN) abdominal malignitelere eşlik edebilir ve kolektomiler sırasında göz önünde bulundurulmalıdır. Çalışmamızda, abdominal maligniteler sebebiyle sağ hemikolektomi uygulanan hastalarda insidental apendiks müsinöz patoloji saptanması halinde tedavi ve takip yaklaşımını değerlendirmeyi amaçladık.

Yöntem: Ocak 2016 - Aralık 2019 yılları arasında genel cerrahi kliniğimizde benign ya da malign nedenler sebebiyle sağ hemikolektomi uygulanan hastaların kayıtları incelendi. Benign nedenlere bağı yapılan hemikolektomiler ve operasyon öncesi appendiks patolojisi saptanan hastalar çalısma dışına alındıktan sonra kalan olgular incelendi. Gastrointestinal veya jinekolojik malignite için sağ hemikolektomi uygulanan hasta dosyaları değerlendirildi. Patoloji sonucu AMN olarak raporlananlar çalışmaya alındı. insidental olarak saptanan AMN'ler değerlendirilerek literatürle karşılaştırıldı.

Bulgular: 214 hastanın gastrointestinal veya jinekolojik kaynakli malignite sebebi ile sağ hemikolektomi uygulanan 167' si calısmaya alındı. Hastaların 80'i kadın, 87'si erkek idi. Yaş ortalaması 63 (23-95) idi. Kliniğimizde üç yıllık sürede malignite sebebiyle sağ hemikolektomi operasyonu geçiren hastalarda AMN insidansı \%2.9 idi. Patoloji raporlanmasinda 3 hastada (\%60) musinoz neoplazi, 1 hastada (\%20) musinoz kistadeno kanser saptandı. 1 hastada ise (\%20) appendiks karsinoid tümörüyle karsıılașıldı.

Sonuç: AMN nadir görülen bir antitedir ve malignite nedenli sağ hemikolektomilerde akılda olmalıdır.Yapılacak rezeksiyonlar malignite cerrahisi prensipleri gözetilerek gerçekleştirilmelidir. Hastaların preoparatif değerlendirmeleri dikkatle yapılmalı, tedavileri postoperatif patoloji sonuçlarına göre yönlendirilmeli ve hastalar gelişebilecek kolorektal tümörler açııından takip edilmelidir.

Anahtar kelimeler: appendektomi, insidental, tümör, appendiks neoplazmı

Corresponding Author:

drsalihtosun@yahoo.com
S. Tosun 0000-0002-5033-4477

O. Yener 0000-0001-5488-4583

O. Ekinci 0000-0002-2020-1913

I.M. Leblebici 0000-0002-1403-7643
A.Y. Serdaroglu 0000-0001-5263-6252

M. Acar 0000-0002-6095-4522

T. Soylemez 0000-0003-3030-7030

O. Alimoglu 0000-0003-2130-2529

(c) Telif hakkı Sağlık Bilimleri Üniversitesi Bakırköy Dr. Sadi Konuk Eğitim ve Araştırma Hastanesi'ne aittir. Logos Tıp Yayıncılık tarafindan yayınlanmaktadır. Bu dergide yayınlanan bütün makaleler Creative Commons Atff-GayriTicari 4.0 Uluslararası Lisansı ile lisanslanmıştr.

(c) Copyright Health Sciences University Bakırköy Sadi Konuk Training and Research Hospital. This journal published by Logos Medical Publishing.

Licenced by Creative Commons Attribution-NonCommercial 4.0 International (CC BY-NC 4.0) 


\section{INTRODUCTION}

Mucocele is a rare appendiceal pathology $(0.2-0.7 \%$ of all appendectomy specimens) ${ }^{(1-3)}$. Appendiceal mucinous neoplasms (AMNs) are very rare with 1000 to 2000 cases diagnosed annually in the United States ${ }^{(4)}$ and they are responsible about $1 \%$ of all cancers worldwide ${ }^{(5)}$. AMNs include a heterogeneous group of diseases and their malignancy potential varies as seen in different classification systems ${ }^{(6-8)}$. Different classifications with similar terminology were suggested to define lesions of variable biologic potential by several authors. Not only classification but also management of AMNs are also problematic for clinicians ${ }^{(7,8)}$. A remarkable part of the lesions is asymptomatic, and they are incidental findings at surgeries AMNs are usually diagnosed incidentally during surgery performed for suspiect cases of appendicitis ${ }^{(9)}$. Advanced stage of AMN is observed with abdominal distension related to the accumulation of mucin in the peritoneal cavity. These tumors may disseminate throughout the peritoneal cavity in the form of gelatinous deposits; the worst complication of AMNs called peritoneal pseudomyxoma, caused by spontaneous or iatrogenic appendix perforation with high rate of morbidity and mortality $(10,11)$. Also, there are no clear guidelines on the extent of surgical resection; therefore, many reports on surgical procedures have been published ${ }^{(3,12)}$. Considering uncertain potential malignant progression, an early and accurate preoperative identification of AMNs confined to the appendix is crucial for prediction of prognosis and decision on treatment strategy ${ }^{(13)}$.

In our study we aimed to evaluate the treatment and follow-up approach to the patients who had incidentally detected appendiceal mucinous pathology following right hemicolectomy performed for abdominal malignancies.

\section{MATERIAL and METHODS}

\section{Patients, inclusion and exclusion criteria:}

We have analyzed the records of the patients who underwent right hemicolectomy performed due to benign or malign conditions in our general surgery clinic between January 2016 and December 2019. The records were analyzed for demographics, sur- gery reports, pathology results and long-term outcomes.

Patients with a history of a previous operation for benign conditions, such as acute appendicitis or with a radiographically or pathologically confirmed appendicitis before the primary surgery were excluded from the study. After exclusion of patients who had undergone hemicolectomies due to benign causes and appendiceal pathologies detected before the operation, records of remaining patients were evaluated.

We have identified the cases matching the inclusion criteria that was pre-described as malignancy. Physical examination notes, operation, and the pathology records as well as clinical data of all included patients were carefully reviewed.

The patients with a final pathological diagnosis of appendiceal mucinous neoplasm were also included in the study. The incidence of appendiceal mucinous pathology was analyzed and compared with the literature. The AMN cases were re-examined and evaluated based on pathology reports recorded during the study.

\section{Pathologic evaluation:}

Appendiceal mucinous pathology (intracytoplasmic mucine containing nuclear atypia) was identified in histological specimens (Figure 1).

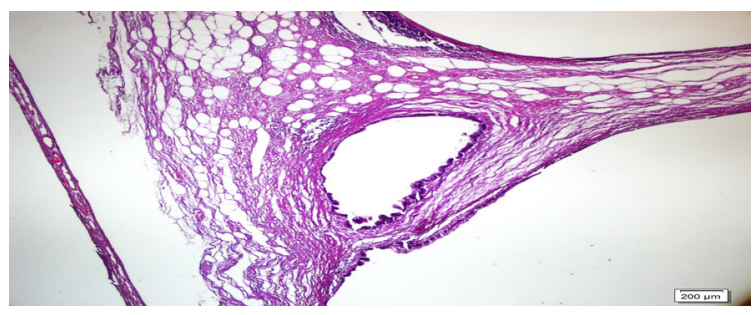

Figure 1. Neoplastic columnar cells with mild intracytoplasmic mucine containing nuclear atypia (HE X40, X200).

Ethics committee approval was obtained. All patients were evaluated in follow-up visits after surgery.

\section{RESULTS}

There were 214 patients who underwent right hemicolectomy due to benign or malign conditions in our general surgery clinic in three years period. A total of 
167 (78\%) patients were included in the study who had medical history of a gastrointestinal or gynecologic malignancy and underwent primary surgery.

A total of 167 cases who underwent right hemicolectomy due to malignancy; consisted of $80(47.9 \%)$ female and $87(52.1 \%)$ male patients. The mean age of the patients was 63 (23-95) years.

In the present study, 5 of the 167 cases evaluated were diagnosed with appendiceal mucinous neoplasms by histomorphological and architectural findings and two of them had lesions of $>2 \mathrm{~cm}$ in diameter. The study population consisted of four women and one man. The median age of these patients was 52 (23-63) years. The incidence of appendiceal mucinous neoplasm was $2.9 \%$ in patients who underwent right hemicolectomy for gastrointestinal or gynecologic malignanacies from January 2016 to December 2019 in surgery department (Figure 2).
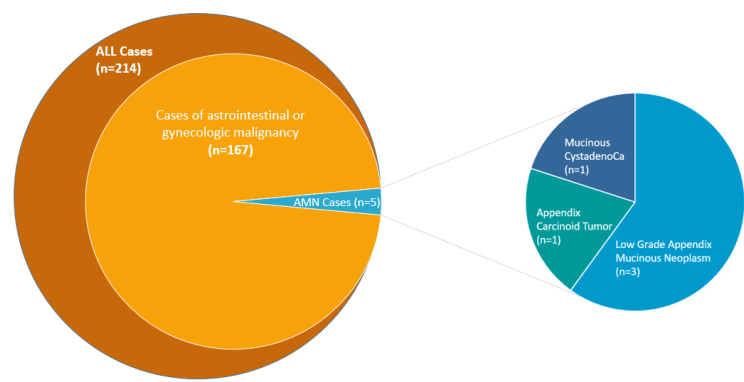

Figure 2. Distrubition of appendiceal mucinous pathology among patient $s$ who underwent right hemicolectomy.

Three out of five cases (60\%) had been diagnosed with low-grade appendiceal mucinous neoplasms according to pathological reports of specimens during the study. One out of five patients $(20 \%)$ was diagnosed with mucinous cystadeno cancer and one out of five patients (20\%) was diagnosed with an appendiceal carcinoid tumor.

\section{DISCUSSION}

Primary neoplasms of appendix are rarely seen (less than $2 \%$ of surgical appendectomy specimens) and their major categories include epithelial tumors, mesenchymal tumors, and lymphomas. AMNs is a complex, diverse group of epithelial neoplasms often causing cystic dilation of the appendix due to the accumulation of gelatinous material, morphologically referred to as mucoceles ${ }^{(14)}$.

AMN is an infrequently seen adenoma which can either be in the appendix or the surrounding appendiceal mucosa wall. Mucoceles are also very rare seen $(0.2 \%$ and $0.7 \%)$ among all appendectomy specimens. They affect women 4 times more than men. Appendiceal mucinous lesions (both benign and neoplastic) have also a slight female predominance ${ }^{(15,16)}$. In our study, $80 \%$ of the cases were female. AMNs are usually diagnosed in patients in their $50 \mathrm{~s}$ and $60 \mathrm{~s}{ }^{(15,16)}$. In our case series the medan age of these patients was 52 years.

Patients with AMN can present with intussusception, abdominal pain and obstruction. However, these neoplasms are often found incidentally in asymptomatic patients. AMNs are requentlymis diagnosed as acute appendicitis, retroperitoneal tumors of the right iliac fossa, or an adnexal mass of ${ }^{(17)}$. Ultrasound and CT (the most commonly used radiographic interpretation for preoperative diagnosis) are the main imaging techniques in terms of diagnosis ${ }^{(13,18)}$. Cystic dilation of appendiceal lumen, calcifications of appendiceal wall and irregular appendiceal wall thickening are common abdominal CT findings.

In pathological examination; appendiceal wall hyalinization and fibrosis with a grossly swollen appendix secondary to mucinous accumulation (19) can be seen. Histological characteristics of AMNs usually present as atypical glandular cells and epithelial cells with "pushing invasion" of malignant cells creeping into the appendiceal wall with possible diverticular formation. Mucinous cells, goblet cells among colon cells are frequently identified within AMNs ${ }^{(20)}$. AMNs of $<2 \mathrm{~cm}$ diameter are rarely malignant and usually classified as benign simple or retention mucoceles. AMNs of $>6 \mathrm{~cm}$ represent high risk of malignancy, appendiceal perforation, and development of pseudomyxoma peritonei ${ }^{(21)}$. Two of our cases had lesions of $>2 \mathrm{~cm}$ in diameter. One of them was diagnosed with mucinous cystadenocancer while the other patient was diagnosed with appendiceal carcinoid tumor.

Controversies remain as to the best surgical approach (laparoscopic vs open), adjuvant therapy, duration of 
follow-up, and imaging technique. The goal of the AMN management includes the prevention from rupture, seeding, and pseudomyxoma peritonei ${ }^{(22)}$. Right hemicolectomy in the absence of lymph node metastasis has been replaced by appendectomy which is the only approach used for the treatment of benign appendiceal mucoceles. Upon the discovery of submucosal malignancy, infiltration or lymph node metastasis, right hemicolectomy with or without omentectomy may be performed.

In our study, incidentally discovered appendiceal mucinous pathologies were evaluated in right hemicolectomy operations of the patients who underwent surgery for gastrointestinal or gynecologic malignanacies. Incidentally detected appendiceal mucinous pathology is a rare entity.

AMNs can mimick appendicitis and be diagnosed pathologically in less than $2 \%$ of surgical appendectomy specimens ${ }^{(14)}$. The incidence of AMN in colon resection operations is not well defined. In our study, the AMN incidence in right hemicolectomy malignancies was 2.9 percent.

AMNs of $>2 \mathrm{~cm}$ are considered to have malignancy potential and right hemicolectomy is the recommended surgical treatment in such cases ${ }^{(23)}$. Any appendiceal abnormality was not detected before surgery in our patients. We identified $5 \mathrm{AMN}$ cases for whom we performed right hemicolectomy for gastrointestinal or gynecologic malignancies in our records.

Pathology reports revealed appendiceal mucinous pathologies in these patients. Thus, any further surgical and adjuvant therapies were not required in these cases.

\section{CONCLUSIONS}

Overall, further studies are needed to identify the best diagnostic method and treatment approach for appendiceal mucinous pathology. There remains a lack of standardization for post-treatment surveillance. AMNs should be considered during the colectomy operations of different malignancies and resections must follow principles for malignancy surgery We recommend exploring the appendix for any potential AMNs while performing colectomies due to any reason.

Ethics Commitee Approval: S. B. Istanbul Medeniyet University Göztepe Training and Research Hospital Clinical Research Ethics Committee (2020 / 0120, 19.02.2020)

Conflict of interest: The authors declare no conflict of interest.

Funding: No financial support was received.

Informed Consent: Not obtained since the study is retrospective.

\section{REFERENCES}

1. Honnef I, Moschopulos M, Roeren T. Appendiceal mucinous cystadenoma. Radiographics. 2008;28(5):1524-7. https://doi.org/10.1148/rg.285075160

2. Karakaya K, Barut F, Emre AU, et al. Appendiceal mucocele: case reports and review of current literature. World J Gastroenterol. 2008;14(14):2280-3. https://doi.org/10.3748/wjg.14.2280

3. de Abreu Filho JG, de Lira EF. Mucocele of the appendix appendectomy or colectomy? J Coloproctol. 2011;31(3):27684.

https://doi.org/10.1590/S2237-93632011000300008

4. Choudry HA, Pai RK. Management of mucinous appendiceal tumors. Ann Surg Oncol. 2018;25(8):2135-2144. https://doi.org/10.1245/s10434-018-6488-4

5. Pai RK, Longacre TA. Appendiceal mucinous tumors and pseudomyxoma peritonei: histologic features, diagnostic problems, and proposed classification. Adv Anat Pathol. 2005;12(6):291-311.

https://doi.org/10.1097/01.pap.0000194625.05137.51

6. Dixit A, Robertson JH, Mudan SS, Akle C. Appendiceal mucoceles and pseudomyxoma peritonei. World J Gastroenterol. 2007;13(16):2381-4.

https://doi.org/10.3748/wjg.v13.i16.2381

7. Panarelli NC, Yantiss RK. Mucinous neoplasms of the appendix and peritoneum. Arch Pathol Lab Med. 2011;135(10):1261-8. https://doi.org/10.5858/arpa.2011-0034-RA

8. Carr NJ, Cecil TD, Mohamed F, et al. A consensus for classification and pathologic reporting of pseudomyxoma peritonei and associated appendiceal neoplasia: The results of the Peritoneal Surface Oncology Group International (PSOGI) modified delphi process. Am J Surg Pathol. 2016;40(1):1426. https://doi.org/10.1097/PAS.0000000000000535

9. Isaacs KL, Warshauer DM. Mucocele of the appendix: computed tomographic, endoscopic, and pathologic correlation. Am J Gastroenterol. 1992;87(6):787-9. PMID: 1590322.

10. Que $Y$, Tao C, Wang X, Zhang Y, Chen B. Pseudomyxoma peritonei: some different sonographic findings. Abdom Imaging. 2012;37(5):843-8. https://doi.org/10.1007/s00261-012-9843-0

11. Yantiss RK, Shia J, Klimstra DS, Hahn HP, Odze RD, Misdraji J. Prognostic significance of localized extra-appendiceal mucin deposition in appendiceal mucinous neoplasms. Am J Surg Pathol. 2009;33(2):248-55. https://doi.org/10.1097/PAS.0b013e31817ec31e

12. Kwak HD, Ju JK. A prospective study of discrepancy between clinical and pathological diagnosis of appendiceal mucinous 
neoplasm. Ann Surg Treat Res. 2020;98(3):124-9.

https://doi.org/10.4174/astr.2020.98.3.124

13. Yu X, Mao J, Tang W, et al. Low-grade appendiceal mucinous neoplasms confined to the appendix: clinical manifestations and CT findings. J Investig Med. 2020;68(1):75-81. https://doi.org/10.1136/jim-2018-000975

14. Foster JM, Gupta PK, Carreau JH, et al. Right hemicolectomy is not routinely indicated in pseudomyxoma peritonei. Am Surg. 2012;78(2):171-7.

PMID: 22369825. https://doi.org/10.1177/000313481207800234

15. Jarvinen $P$, Jarvinen $H J$, Lepisto A. Survival of patients with pseudomyxoma peritonei treated by serial debulking. Colorectal Dis. 2010;12(9):868-72. https://doi.org/10.1111/j.1463-1318.2009.01947.x

16. Landen S, Bertrand C, Maddern GJ, et al. Appendiceal mucoceles and pseudomyxoma peritonei. Surg Gynecol Obstet. 1992;175(5):401-4. PMID: 1440166

17. Pai RK, Beck AH, Norton JA, et al. Appendiceal mucinous neoplasms: clinicopathologic study of 116 cases with analysis of factors predicting recurrence. Am J Surg Pathol. 2009;33(10):1425-39. https://doi.org/10.1097/PAS.0b013e3181af6067

18. Shaib WL, Assi R, Shamseddine A, et al. Appendiceal mucinous neoplasms: diagnosis and management. Oncologist. 2017;22(9):1107-16. https://doi.org/10.1634/theoncologist.2017-0081

19. Ashrafi M, Joshi V, Zammit M, et al. Intussusception of the appendix secondary to mucinous cystadenoma: A rare cause of abdominal pain. Int J Surg Case Rep. 2011;2(2):26-7. https://doi.org/10.1016/j.ijscr.2010.11.004

20. Caspi B, Cassif E, Auslender R, Herman A, Hagay Z, Appelman $Z$. The onion skin sign. a specific sonographic marker of appendiceal mucocele. J Ultrasound Med. 2004;23(1):11721. https://doi.org/10.7863/jum.2004.23.1.117

21. Hoeffel C, Crema MD, Belkacem A, et al. Multi-detector row CT: spectrum of diseases involving the ileocecal area. Radiographics. 2006;26(5):1373-90.

https://doi.org/10.1148/rg.265045191

22. Ronnett BM, Yan H, Kurman RJ, Shmookler BM, Wu L, Sugarbaker PH. Patients with pseudomyxoma peritonei associated with disseminated peritoneal adenomucinosis have a significantly more favorable prognosis than patients with peritoneal mucinous carcinomatosis. Cancer. 2001;92(1):8591.

https://doi.org/10.1002/1097-0142(20010701)92:1<85::AIDCNCR1295>3.0.CO;2-R

23. Glasgow SC, Gaertner W, Stewart D, et al. The American Society of Colon and Rectal Surgeons, Clinical Practice Guidelines for the Management of Appendiceal Neoplasms. Dis Colon Rectum. 2019;62(12):1425-38. https://doi.org/10.1097/DCR.0000000000001530 